\title{
Global environmental, social and economic crises: Voluntary corporate activities as a possible solution
}

\author{
Marie DOČEKALOVÁ, Alena KOCMANOVÁ, Brno University of Technology ${ }^{\mathrm{i}}$
}

\begin{abstract}
The article deals with the global problems of mankind, which are causing environmental, social and economic crises. Another possible cause of crises is the failure of the government and management of companies (corporate governance). Based on a literature review, this article aims to define and categorize global problems and to discuss selected approaches to crisis solutions. While activities to solve crises on a macro level appear to be inefficient, the initiatives of companies will play a key role in the resolution of instability in a global system. The incorporation of sustainability into corporate governance through responsible investment, transparent reporting, corporate social responsibility, etc. should bring stability and sustainability to a global system.
\end{abstract}

\section{Keywords}

Corporate governance, corporate sustainability reporting, economic crisis, environmental crisis, social crisis, socially responsible investing, sustainable development.

JEL Classification: Q01, G30

\footnotetext{
${ }^{\mathrm{i}}$ Department of Economics, Faculty of Business, Brno University of Technology, Kolejní 2906/4, 61200 Brno, Czech Republic.

This paper is supported by the Czech Science Foundation. Name of the Construction of Methods for Multifactor Assessment of Company Complex Performance in Selected Sectors. Reg. No. P403/11/2085.

docekalova@fbm.vutbr.cz (corresponding author)
}

\section{Introduction}

The term 'global crisis' is a frequently used feature of a contemporary world and should cover the actual problems entirely. However, is it possible to express so many dimensions and partial definitions of various pages of reality and their topics in one allencompassing expression - a crisis? It is obvious that the concept of a crisis as an axiom will probably not be enough; on the other hand, we cannot be satisfied with its negation, with a simple and unproved claim that there is no crisis and no danger from it (Jemelka, 1998).

The article focuses on selected aspects of environmental, social and governance crisis. Another important aspect is economic crisis. It should be stressed that these parts cannot be separated and considered individually. On the contrary, these individual components are closely related, conditioning and passing one into another. For example, we cannot say that soil degradation is a purely environmental issue. The cause and effect of this problem fall into both the social and the economic sphere and it influences government and company management.

Sections 2 and 3 aim to define and categorize the global problems of humanity and to list the causes of crises in the social, environmental and economic fields. Section 4 discusses the selected approaches to crises and global problems' solutions. While activities to solve crises on the macro level appear to be inefficient and at best only partially effective, companies' 
initiatives could significantly contribute to the solution to instability in a global system. The incorporation of sustainability into companies' management through responsible investment, transparent reporting, corporate social responsibility, the cultivation of corporate governance, complex measurement and the management of corporate performance and its reporting should all in the long term lead to positive effects, such as poverty reduction, conflict prevention, the development of developing economies and climate change prevention and thus to greater stability and sustainability of a global system.

\section{Global environmental and social problems}

Although we cannot easily categorize and separate environmental, social and economic aspects and the relationship of government to them, we can show their mutual relations. This is appropriate simply because they exist neither independently nor side by side. There is no observed linear relationship, but a vertical relationship (relations of superiority and inferiority, i.e. we provide their hierarchy). From the picture published on the website of Cornell University, the fundamental relationship between these aspects is evident; see figure 1 .

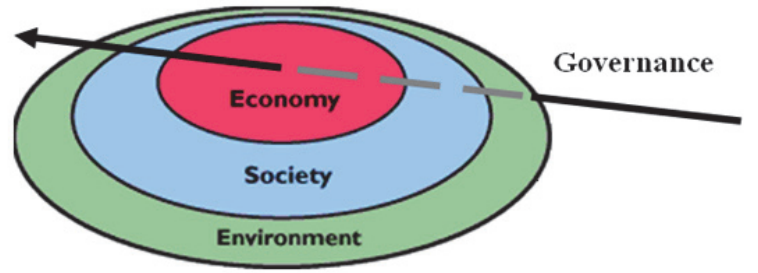

Figure 1 Sustainable development

Source: Own processing based on the diagram of sustainable development of Cornell Sustainability Campus (Cornell University, 2010)

Society and economy are limited by the environment and growth of the economy and industry is limited not only by the environment but also by the limits of the society.

Figure 1 represents three pillars of sustainability and is adjusted to the government's influence. It can be argued that the government is part of the social pillar, but the picture is not completed by the relation of the superiority of the government, because it is clear that governments operate within the society, but it is completed by the relationship of regulation. A government regulates and sets rules in the field of the environment but also in those of society and economy.

Environmental problems (global warming, soil degradation and others) are closely linked to and determine each other, and therefore the solution must be comprehensive and appropriate for their causes (Damohorský, 2007).
Environmental and social problems cannot be separated and can be sorted into a common category of eco-social problems.

Eco-social problems stem from a broken relationship between society and nature. This group includes all global environmental problems:

- Population problem: the population reached its first billion at the turn of the eighteenth and nineteenth centuries. From the beginning of the nineteenth to the end of the twentieth century, five billion inhabitants arrived on the Earth. So, the first billion took tens of thousands of years, while for the last one only twelve years were needed; see figure 2. The largest population growth is in the so-called Third World, which suffers from a lack of food, a high incidence of disease, etc. (Heczko, 2005; Mezřický, 2005).

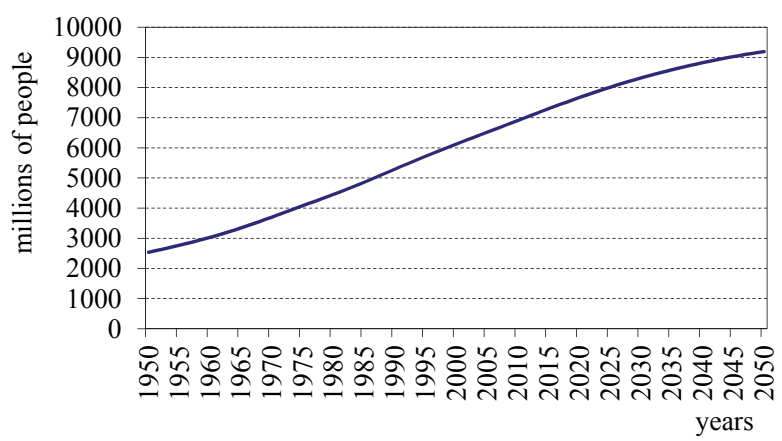

Figure 2 Development of the human population Source: Own processing based on the OECD (2010)

- Food (nutrition) problem: about one billion people suffer from long-term hunger. This problem exists because of poverty and natural disasters (earthquakes, floods, long drought). Most people suffering from hunger live in developing countries; see figure 3 (FAO, 2011).

- Raw materials and energy problem: the scarcity of non-renewable resources; the threat of the so-called oil crash (Heczko, 2005).

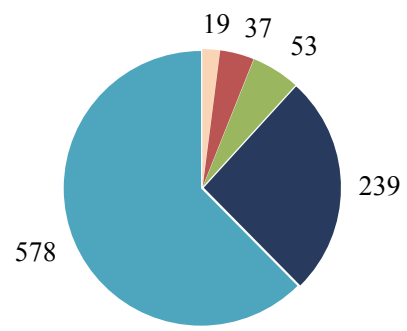

$$
\begin{array}{ll}
\text { Developed countries } & \text { Near East and North Africa } \\
\text { Latin America and the Caribbean } & \text { Sub-Saharan Africa } \\
\text { - Asia and the Pacific } &
\end{array}
$$

Figure 3 Undernourishment in 2010, by region (millions) Source: Own processing based on The State of Food Insecurity in the World (FAO, 2011) 
Inter-social problems arise in the relations between people (relation man-man) and they are associated with major conflicts of interests of various social and economic groups and systems:

- The problem of war and peace: nuclear, chemical and biological disasters and conflicts,

- the problem of the socio-economic backwardness of developing countries,

- the problem of international debt (the debt crisis of developing countries),

- the problem of changes in international economic relations: striving for New International Economic Order (NIEO), including problems of access to developed countries' markets for goods from developing countries, fairer trade rules and debt relief for poor countries (Heczko, 2005).

Anthropo-social issues concern the future of humans; they usually fall into one category of problems:

- General human problems in social, humanitarian and cultural fields. In this context it is often referred to as the general problem of the future of man, which is then further divided into 10 to 15 sub-problems, such as the problem of absolute poverty (the international poverty line is the daily income of 1 U.S. dollar), the problem of the spread of epidemics and drug addictions, the problem of uncontrolled international migration (the refugee problem) and the problem of terrorism, nurtured by political and ethnic conflicts (Heczko, 2005).

\section{Economic crises}

All of the above-mentioned global problems have an economic dimension. Thus, social and environmental problems cause economic crises. Economics meets psychology, socio-biology, evolutionary theory and even neurosciences. The behaviour of neurons in our brains recalls the behaviour of other complex and interactive systems - from environmental to economic ones. Simple causes in them have complex, often paradoxical effects. A Darwinism, the survival of the fittest (implying more resistance and a greater capability to reproduce, adapt and manage the demands), is applied to them. However, in such an environment also originate cooperation, altruism and self-sacrifice - all due to very complex, but quite understandable reasons (Němeček and Kocmanová, 2009).

The worst economic crisis to date with a significant social impact is considered to be the Great Depression, which broke out on 24 October 1929 when shares on the New York Stock Exchange crashed. There are many explanations for it, many of which are strongly politically tainted. It was, however, in partic- ular a system error and mainly at the micro-economic level. It is clear that the interconnection of commercial and investment banking was erroneous; it had already been disabled in 1932 by the Glass-Steagall Act (see e.g. Kregel, 2010; Kroszner and Rajan, 1994). Compulsory insurance of deposits and laws to protect small shareholders were also introduced. The approach of the Federal Reserve System in the late 1920s and 1930s was also apolitical, focusing exclusively on maintaining the gold standard at any cost. The gold standard was already outdated by that time. A characteristic feature of this period was a decline in industrial production. The agriculture sector was mainly hit by a significant fall in the prices of products and a reduction in investment. Foreign trade fell apart as well, since such a situation required the creation of international cartels and monopolies. A major problem was the huge level of unemployment, which affected all the countries influenced by the crisis (Hornungová and Klímková, 2010; Klímková, 2009; Volek, 2002; Žídek, 2007).

Another possible cause of an economic crisis is a failure of governance. We can understand governance as state-level governance or corporate governance. Today's global economic crisis is proof that the underestimation of environmental and social aspects and the failure of corporate governance and the government of countries lead to a deep global economic crisis.

In general, views on the current crisis can be found on a scale from it was an accident to it revealed serious problems. Proponents of the first view believe that an extraordinary and unique set of circumstances resulted in the crisis and could not be predicted. According to the second view, the crisis has exposed the fundamental instability and lack of sustainability in the global economic and financial system. Along with the threat of climate change and other macro challenges, there must be a fundamental review of the control of corporate governance (Lenssen et al., 2010).

The cause of the crisis was a failure of the corporate governance of banks and other financial institutions (including credit rating agencies). Criticism is hitting even EU institutions, whose follow-up rescue measures released these institutions from responsibility (De Grauwe, 2010). In connection with the causes of the crisis and therefore with the irresponsible behaviour of companies, the Nobel Prize laureate economist Joseph Eugene Stiglitz introduced the term moral hazard. The billion euros spent are a typical example of a moral hazard.

Optimists argue that the crisis is ending, but despite all the efforts and resources used, we cannot simply say that the crisis is over. Instability continues 
with the state debt crisis in the eurozone and a solution is not in sight (see e.g. Aslund, 2011; Silva, 2011; Wihlborg et al., 2010).

Europe is not suffering only from a debt crisis, affecting Greece, Spain, Italy and Portugal. Another important problem is unemployment. The average rate of unemployment in the EU is more than $11 \%$, and in the euro area it is even the highest in its history. Among young people aged under 25 years, this indicator is more than double (Eurostat, 2012).

\section{Discussion about voluntary corporate activities as a potential crisis solution}

There are many ways to solve crises. Solutions can be remedial, i.e. those that mitigate the impacts of the crisis, and preventive, i.e. solutions that should anticipate crises.

The fundamental question remains - why do the proposed solutions not work or are only partially successful? One reason is surely that global problems require global solutions. If there is still no international authority able to make the world act responsibly with regard to the environment, world society and global economy, we are likely to face global crises again in the future. Another obstacle to effective functioning is that these arrangements are mostly based on the principle of voluntariness.

It is also critically assessed that the real results of initiatives in resolving crises and in sustainable development are not seen, and whether we have made real progress towards a sustainable society remains questionable, because too many unsolved problems persist; in fact, some problems have even intensified (Baumgartner, 2011).

Within the group of solutions at the macro level may generally fall the global efforts to achieve a better world, which are often institutionalized within international organizations (such as the United Nations, the Organization for Economic Cooperation and Development, the World Fair Trade Organization).

To resolve global problems, solutions at the global level and their global acceptance are key. However, companies influence directly and significantly the environment, community and economy with their activities.

There are many companies' efforts and activities that can help improve the state of the world. It is important to note that companies do not create these efforts primarily for altruistic reasons but because they see a competitive advantage there. A weakness is that in some cases they are not conducted properly and in depth, but only superficially, creating only the impression of responsibility.
Among the approaches at the micro level - on the level of companies - these efforts can include the cultivation of corporate governance, sustainable business, socially responsible investing, corporate social responsibility, corporate sustainability reporting and complex corporate performance measurement.

\subsection{Cultivation of corporate governance}

As a result of the collapse of large companies, the voices calling for the adoption of stricter economic, financial and accounting regulations have intensified. Companies should take lessons from these cases and not limit themselves only to reviewing financial information. We deal with the issue of corporate governance if there is separate management of a company from its owners.

Corporate governance, as defined by the Organization for Economic Cooperation and Development, represents a system of conducting and controlling companies. The system defines the distribution of rights and obligations between stakeholders, such as shareholders, executive management, statutory bodies, employees, customers, etc. It comprises a set of legal and executive methods and procedures, which bind mostly publicly traded companies to maintain a balanced relationship between a company and those who form it.

The OECD established general rules for proper corporate governance - Principles of Corporate Governance. These rules are aimed at strengthening the rights of shareholders and other stakeholders (including creditors), preventing conflicts of interest, creating more transparent rules for the remuneration of executives and managers, transparency and responsibility.

The Principles of Corporate Governance are closely linked to the cultural factors of a certain community and are formulated in very general terms and only their implementation at the national level will take into account all these aspects and enable the creation of optimal rules that are most suitable for a given business environment. The OECD seeks to promote the implementation of these rules at a regional level through so-called regional round tables that create a space for discussion and mutual exchange of information between experts from the public and private fields. The most serious problem of corporate governance is seen as a lack of transparency in companies' activities and little responsibility for the resulting consequences (OECD, 2004; OECD, 2011).

\subsection{Sustainable business}

A sustainable business is a business that contributes to a fair and environmentally sustainable economy (Sustainablebusiness.com, 2011). 
According to the largest study of CEOs, the sustainability issues will be important to the future success of corporations for $93 \%$ of them. In 2007, $72 \%$ of CEOs believed that sustainability issues should be fully integrated into the strategy and operation of a company and in 2010 this figure had already increased to $96 \%$ of believers, demonstrating the growing interest in sustainability (Lacy et al., 2010).

\subsection{Corporate social responsibility (CSR) and socially responsible investing (SRI)}

CSR can be defined as the voluntary integration of social and environmental aspects into everyday business operations and interaction with corporate stakeholders. CSR encourages companies to change their orientation from short-term goals to long-term goals, and from maximum profit to optimal profit. Profits for socially responsible companies can be for example an opportunity for innovation, greater attraction for investors, greater transparency, enhanced credibility, increased loyalty and productivity of employees, building of reputation and the resulting strong market position, dialogue and building relationships of trust with the surroundings and the resulting mutual understanding, as well as the reduced risk of boycotts and strikes (Trnková, 2004).

An investment is closely related to a business. Socially responsible investing attempts to include environmental and social factors in the investment process (also called sustainable investing) (Principles for Responsible Investment, 2010).

This method of investing allows investors to achieve their investment objectives and at the same time brings sustainability to the global economy.

\subsection{Complex measurement of corporate perfor- mance}

In the context of the crisis, the question of acceptable revenues and the need for alternative methods of measurement was re-opened, which would include long-term sustainability and the ability to manage externalities, environmental, economic and social aspects and increased public demands for companies that should express that they contribute positively to the overall social welfare. It seems that companies will no longer be evaluated solely on their financial performance, enforced by shareholders and by their demands for immediate profits. It is expected that companies will instead monitor to a much greater extent their impact on the society in which they operate and show increased interest in it (Berthon, 2010).

The use of classic or modern financial performance indicators for the evaluation of companies' overall performance and sustainability does not have a sufficient explanatory value.

Despite academic and business professionals' efforts, there has as yet been no conclusive evidence that could universally either confirm or disapprove a direct causal link between environmental, social and corporate governance (ESG) performance and corporate financial performance (Barnett and Salomon 2006; Bassen and Kovács, 2008; Horváthová, 2010; LópezGamero et al., 2009; Salo, 2008). In spite of that, ESG activities may potentially have a positive impact on financial and overall performance, as represented in table 1 .

It is important to create measurable and relevant objectives for sustainable development and appropriate metrics. Furthermore, integrated reporting of financial and non-financial information is necessary. Companies that provide insufficient and incomplete information are considered by investors to be more risky and therefore investors are willing to invest less money in these companies. The solution offers corporate sustainability reporting, which integrates financial and non-financial indicators. The same principles should be applied to both financial and non-financial indicators. In both cases the indicators should be relevant, measurable, comparable, motivating and transparent. Financial performance is usually measured by indicators based on accounting, such as earnings per share. ESG metrics are most often not accounting-based, and they are criticized as being too vague and general (Kruse and Lundbergh, 2010).

In a company with poor ESG performance:

- no data are available,

- instead of relative indicators a company offers just absolute ones,

- trends are not explained,

- environmental and social management standards are defined but referred to only slightly,

- strategic plans are not satisfactory,

- ESG is an issue for lower management but not for top management, and there is no cooperation with shareholders (Dowse, 2009).

If performance can be defined as a measure of the achievement of results, then the integration of environmental, social and economic performance should mean results achievement in the environmental, social and economic fields, while these objectives should not be in mutual conflict. A company should therefore influence systematically all three pillars of management simultaneously, implement voluntary instruments for the improvement of environmental and social performance and use appropriate means to ensure a sufficiently high profit.

For performance monitoring of all three areas, it is necessary to introduce corporate sustainability report- 
ing. Social and environmental reports may be published separately, but the publication of these aspects of business activities in connection with economic information in one document provides a comprehensive picture of a company.

The most important initiative for reporting on sustainable development is the Global Reporting Initiative (GRI). The GRI is an initiative of the United Nations. The idea of creating a framework for reporting on sustainability was conceived in 1997. The GRI's vision is that reporting on the economic, social and environmental performance of a company should become common and comparable, just as financial reporting, and equally important to the success of an organization (GRI, 2011).

In 2009, the Amsterdam Declaration On Transparency and Reporting was issued, within which the GRI's Board of Directors challenged governments to introduce national strategies for sustainable development, which require organizations to publish ESG indicators in their voluntary reports. The declaration states that the causes of the current economic crisis could be identified by the global transparency of a reporting system of organizations based on carefully and publicly reported ESG performance. The declaration calls on governments to assume leadership for economic reconstruction and for the recovery into a flexible economic system, through which the following can be achieved:

- The implementation of company policies (strategy) requires that ESG indicators are reported, or it is publicly explained why the company does not do so.

- By requiring ESG reporting from public institutions - in particular for: public companies, government and public pension funds, and investment agencies.

- Integrating reports within the newly emerging global financial regulatory framework, as suggested by G20 officials.

Previous intergovernmental meetings have recognized the need for publishing voluntary reports with sustainability indicators at the 2007 G8 summit in the German Heiligendamm, where GRI reporting was officially supported. It should serve as a means to obtain good governance of public matters, and their transparency, and so achieve a reduction of poverty, conflict prevention, promotion of sustainable investment decision-making and support of development in developing economies (Hřebíček, 2009; Hřebíček et al., 2009a, b; Ritschelová et al., 2008).

\section{Conclusions}

The aim of this article was to define and categorize global problems, which may be seen as pointless due to the complexity of the world. However, if we are looking for a specific solution, it is practical. The text indicates that these solutions must be comprehensive. Only a few approaches were stated in the environmental, social and economic fields.

The article presented voluntary corporate activities as possible solutions to crises, as well as activities that should have a preventive function. Corporate voluntary initiatives and activities should be a more effective solution than institutionalized international activities. Companies can, by integrating elements of sustainable development into their management, in a relatively short period of time contribute to greater stability of the global system, just as they can destabilize the system in a short period of time with irresponsible behaviour. A key role in further development will be played by corporate governance. The cultivation of corporate governance, admission of responsibility for further world development and recognition of legitimate requirements of all stakeholders - all accompanied by responsible actions, such as responsible investment, sustainable business, re-orientation from short-term financial profits to long-term prosperity, integration of environmental and social aspects into one system of performance measurement and a performance management system accompanied by transparent reporting - should bring positive effects, such as: delaying the threat of climate change, the reduction of poverty, conflict prevention and the reduction of social tension, etc., and so lead to greater stability and sustainability of the global system.

\section{References}

BARNETT, M.L., SALOMON, R.M. (2006). Beyond ditochomy: the curvilinear relationship between social responsibility and financial performance. Strategic Management Journal 27(11): 1101-1122. http://dx.doi.org/10.1002/smj.557

BASSEN, A., KOVÁCS, A. (2008). Environmental, social and governance key performance indicators from a capital market perspective. Zeitschrift für Wirtschafts- und Unternehmensethik 9(2): 182-192.

BAUMGARTNER, R.J. (2011). Critical perspectives of sustainable development research and practice. Journal of Cleaner Production 19(8): 783-786. http://dx.doi.org/10.1016/j.jclepro.2011.01.005

BERTHON, B. (2010). Responding to the crisis: redefining corporate value. Corporate Governance 10(4): 354-359.

http://dx.doi.org/10.1108/14720701011069588 
DAMOHORSKÝ, M. (2007). Právo životního prostredí. Praha: C. H. Beck.

DOWSE, J. (2009). ESG and due diligence. Keeping Good Companies 61(11): 659-664.

HORNUNGOVÁ, J., KLÍMKOVÁ, M. (2010). Vliv finanční krize na malé a střední podniky v České republice. Trendy ekonomiky a managementu 4(7): $11-17$.

HORVÁTHOVÁ, E. (2010). Does environmental performance affect financial performance? A metaanalysis. Ecological Economics 70(1): 52-59. http://dx.doi.org/10.1016/j.ecolecon.2010.04.004

HŘEBÍČEK, J. (2009). Voluntary reporting in the Czech Republic and indicators of sustainable development. In: Žák, M. (ed.): Sustainability Accounting and Reporting (at Macroeconomic and Microeconomic Level. Praha: Linde, 257-264.

HŘEBÍČEK, J., HÁJEK, M., CHVÁTALOVÁ, Z., RITSCHELOVÁ, I. (2009a). Current trends in sustainability reporting in the Czech Republic. In: WOHLGEMUTH, V., PAGE, B., VOIGHT, K., eds. EnviroInfo 2009. Environmental Informatics and Industrial Environmental Protection: Concepts, Methods and Tools. 23. International Conference on Informatics for Environmental Protection. Aachen: Shaker Verlag, 233-240.

HŘEBÍČEK, J., HÁJEK, M., RITSCHELOVÁ, I., SIDOROV, E. (2009b). Corporate sustainability reporting in the Czech Republic. In: RITSCHELOVÁ, I., ed. Environmental Accounting - Sustainable Development Indicators. Ústí nad Labem: Universita J. E. Purkyně Ústí nad Labem, $12 \mathrm{~s}$.

JEMELKA, P. (1998). Globálnost krize soudobého světa. In: ŠIMEK, D. ed. Člověk a společnost na prelomu tisiciletí. The Individual and Society at the turn of the Century: view from both sides. Olomouc: UP Olomouc, 366-368.

KLÍMKOVÁ, M. (2009). Podnik a štíhlá výroba jako jeden z možných přístupů řešení. In: Lokaj, A., Hlaváček, K., (eds.): "Velká deprese" a její odraz v ekonomické teorii a praxi. Ostrava, VŠB-TU Ostrava, $1-8$.

KREGEL, J.A. (2010). Can a return to GlassSteagall provide financial stability in the US financial system? PSL Quarterly Review 63(252): 37-73.

KROSZNER, R.S., RAJAN, R.G. (1994). Is the Glass-Steagall act justified? A study of the U.S. experience with universal banking before 1933. The American Economic Review 84(4): 810-832.

KRUSE, C., LUNDBERGH, S. (2010). The governance of corporate sustainability. Rotman International Journal of Pension Management 3(2): 46-51. http://dx.doi.org/10.3138/rijpm.3.2.46
LENSSEN, G., BEVAN, D., FONTRODONA, J. (2010). Corporate responsibility and governance: the responsible corporation in a global economy. Corporate Governance: the International Journal of Business in Society 10(4): 340-346.

LÓPEZ-GAMERO, M.D., MOLINA-AZORIN, J.F., CLAVER-CORTES, E. (2009). The whole relationship between environmental variables and firm performance: competitive advantage and firm resources as mediator variables. Journal of Environmental Management 90(10): 3110-3121.

http://dx.doi.org/10.1016/j.jenvman.2009.05.007

MEZŘICKÝ V. (2005). Environmentálni politika a udržitelný rozvoj. Praha: Portál.

NĚMEČEK, P., KOCMANOVÁ, A. (2009). Economic crisis and social responsibility. Economics \& Management 2009(14): 323-327.

RITSCHELOVÁ, I., SIDOROV, E., HÁJEK, M., HŘEBÍČEK, J. (2008). Corporate environmental reporting in the Czech Republic and its relation to environmental accounting at Macro level. In: Csutora, M., Szerényi, Z.M. (eds.) 11th Annual EMAN Conference on Sustainability and Corporate Responsibility Accounting. Measuring and Managing Business Benefits. Budapest: AULA, 55-60.

SALO, J. (2008). Corporate Governance and Environmental Performance: Industry and Country Effects. Competition \& Change 12(4): 328-354.

http://dx.doi.org/10.1179/102452908X357293

WIHLBORGH, C., WILLET, T.D., ZHANG, N. (2010). The Euro debt crisis: it isn't just fiscal. World Economics 11(4): 51-77.

ŽÍDEK, L. (2007). Dějiny světového hospodářství. Plzeň: Aleš Čeněk.

\section{Additional sources}

ASLUND, A. (2011) The Failed Political Economy of the Euro Crisis. [Online], accessed at 15. 03. 2011. Available at: <http://www.economonitor.com/piie/ 2011/11/25/the-failed-political-economy-of-the-eurocrisis/\#idc-container>.

CORNELL UNIVERSITY (2010). Sustainable Development. [Online], accessed at 15. 03. 2011. Available at: $<\mathrm{http}: / / \mathrm{www}$.sustainablecampus.cornell. edu/csi.cfm>.

DE GRAUWE, P. (2010). Crisis in the Eurozone and how to Deal with It (February 15, 2010). CEPS Policy Brief No. 204. [Online], accessed at 01. 08. 2012. Available at: $<$ http://ssrn.com/abstract $=1604453>$.

ESG MANAGERS PORTFOLIOS (2012). What is ESG? [Online], accessed at 27. 07. 2012. Available at: $<$ http://www.esgmanagers.com/Sustainable_Investing/ What_is_ESG>. 
EUROSTAT (2012). Unemployment Rates by Sex, Age and Nationality (\%). [Online], accessed at 03. 08. 2012. Available at: <http://appsso.eurostat.ec.europa. eu/nui/show.do $>$.

FAO (2011). Hunger. [Online], accessed at 27. 07. 2011. Available at: < http://www.fao.org/hunger/en/> .

GRI (2011). [Online], accessed at 27. 08. 2011. Available at: $<$ http://www.globalreporting.org $>$.

HECZKO, S. (2005). Světová ekonomika a globální problémy lidstva. Britské listy. [Online], accessed at 27. 08. 2011. Available at: <http://blisty.cz/art/ 26306.html >.

LACY, P, COOPER, T., HAYWARD, R., NEUBERGER, L. (2010). A New Era of Sustainability: UN Global Compact-Accenture CEO Study. [Online], accessed at 15. 03. 2011. Available at: $<$ www.unglobalcompact.org $>$.

OECD. (2011). About OECD. [Online], accessed at 27. 08. 2011. Available at: <http://www.oecd.org/ pages/0,3417,en_36734052_36734103_1_1_1_1_ $1,00 . h t m l>$.

OECD (2010). OECD Factbook 2010. Economic, Environmental and Social Statistics. [Online], accessed at 27. 08. 2011. Available at: $<$ http://dx.doi.org/10.1787/factbook-2010-en>.
OECD (2004). Principles of Corporate Governance. [Online], accessed at 27. 08. 2011. Available at: $<$ http://www.oecd.org/dataoecd/32/18/31557724.pdf>. PRINCIPLES FOR RESPONSIBLE INVESTMENT (2010). [Online], accessed at 27. 08. 2011. Available at: <http://www.unpri.org/about/>.

SILVA, J.R. (2011). Seeking Solutions to the Crisis of the Euro. [Online], accessed at 7. 11. 2012. Available at:

$<$ https://www.repository.utl.pt/bitstream/10400.5/4138 $/ 1 /$ Seeking $\% 20$ solutions $\% 20$ to $\% 20$ the $\% 20$ crisis $\% 20$ o f\%20the\%20euro.pdf $>$.

SUSTAINABLEBUSINESS.COM. (2011). About us. [Online], accessed at 16. 10. 2011. Available at: $<$ http://www.sustainablebusiness.com/index.cfm/go/in fo.aboutus $>$.

TRNKOVÁ J. (2004). Společenská odpovědnost firem, kompletni prưvodce tématem a závéry $z$ pri̊zkuтu v $\check{C} R$. [Online], accessed at 15. 10. 2011. Available at: <http://www.blf.cz/csr/cz/vyzkum.pdf $>$.

VOLEK, S. (2002). Krach na newyorské burze v roce 1929. [Online], accessed at 02. 08. 2012. Available at: $<$ http://www.penize.cz/inflace/15133-krach-nanewyorske-burze-v-roce-1929>.

\section{Appendix}

Table 1 Potential positive impacts of ESG on overall corporate performance

\begin{tabular}{|c|c|c|}
\hline Area offocus & Activity & Potential impact on financial performance \\
\hline Environmental & $\begin{array}{l}\text { Resource management and } \\
\text { pollution prevention } \\
\text { Reduced emissions and climate } \\
\text { impact } \\
\text { ESG reporting/disclosure }\end{array}$ & $\begin{array}{l}\text { Avoid or minimize environmental liabilities } \\
\text { Lower costs/increase profitability through energy and other } \\
\text { efficiencies } \\
\text { Reduce regulatory, litigation and reputational risk }\end{array}$ \\
\hline Social - Workplace & $\begin{array}{l}\text { Diversity } \\
\text { Health and safety } \\
\text { Labour-management relations } \\
\text { Human rights }\end{array}$ & $\begin{array}{l}\text { Improve productivity and morale } \\
\text { Reduce turnover and absenteeism } \\
\text { Openness to new ideas and innovation } \\
\text { Reduce litigation and reputational risk }\end{array}$ \\
\hline $\begin{array}{l}\text { Social - Product } \\
\text { Integrity }\end{array}$ & $\begin{array}{l}\text { Safety } \\
\text { Product quality } \\
\text { Emerging technology issues }\end{array}$ & $\begin{array}{l}\text { Create brand loyalty } \\
\text { Increase sales based on products' safety and excellence } \\
\text { Reduce litigation and reputational risk }\end{array}$ \\
\hline $\begin{array}{l}\text { Social - Community } \\
\text { Impact }\end{array}$ & $\begin{array}{l}\text { Community relations } \\
\text { Responsible lending } \\
\text { Corporate philanthropy }\end{array}$ & $\begin{array}{l}\text { Improve brand loyalty } \\
\text { Protect license to operate }\end{array}$ \\
\hline Corporate Governance & $\begin{array}{l}\text { Executive compensation } \\
\text { Board accountability } \\
\text { Shareholder rights } \\
\text { Reporting and disclosure }\end{array}$ & $\begin{array}{l}\text { Align interests of shareowners and management } \\
\text { Avoid unpleasant financial surprises or blow-ups } \\
\text { Reduce reputational risk }\end{array}$ \\
\hline
\end{tabular}

Source: ESG Managers Portfolios (2012) 